\title{
The impact of social media usage intensity on self-esteem: survey on emerging adulthood of instagram user
}

\section{Lili Mira Julia Rahma, Setiasih}

Universitas Surabaya, Surabaya, Indonesia

setiasih@staff.ubaya.ac.id

Submitted : 05-02-2021, Revised : 28-04-2021, Accepted : 28-05-2021

\begin{abstract}
Social media can be used to increase individual popularity, one of which is Instagram. Instagram can be used to increase individual self-popularity or increase self-esteem. The purpose of this study, namely to determine the relationship between the intensity of using Instagram and self-esteem in emerging adulthood. This research is a quantitative-survey research, with 259 students at " $X$ " University as many as male and female participants aged 18-25 years. The measuring instrument used is the Rosenberg Self Esteem Scale and the Instagram Intensity Scale. The analysis used was the Spearman non-parametric correlation test. The results show that there is a significant correlation between the intensity of using Instagram and self-esteem on emerging adulthood, there is also a correlation between emotional attachment to Instagram and self-esteem on emerging adulthood. Thus the higher the intensity of using Instagram or the higher the emotional attachment to Instagram, the higher the self-esteem of emerging adulthood. The higher the intensity of a person using Instagram, the higher the desire or motivation of the individual to become more prominent.
\end{abstract}

Keywords: Emerging Adulthood; The intensity of Use of Instagram; Self-esteem

\section{Introduction}

Social media has grown rapidly in the early 2000s and changed the way individuals communicate around the world (Boyd \& Ellison, 2007; Twenge et al., 2019). Not only helps in communicating, social media can also help in many ways, for example: building a business, connecting with other people, as a promotional medium, a source of information and news (Pradiani, 2017; Rahadi, 2017). The development of social media has greatly facilitated the daily life of individuals in various aspects.

This convenience makes the whole world use social media, including Indonesia. Indonesia is the sixth country with a population that spends a lot of time online, which is 195 minutes per day (Duarte, 2019). Social media has many kinds, for example: Facebook, twitter, Instagram and so on.

Instagram is one of the most widely used social media by Indonesians. Data from Napoleon Cat shows the number of Instagram users in Indonesia in January 2020 there were 62.23 million users, and in May 2020 it reached 69.2 million users ((Imam, 2020; Rarasati et al., 2019). About 23 million active Instagram users in Indonesia are aged 18-24 years and in this age range individuals are in adulthood (Arnett, 2014, 2015, 2018; Fitch, 2018; Lantagne et al., 2017; Pertiwi, 2020). This shows that active Instagram users are individuals who enter into developing adulthood. Emerging adulthood is a period of transition from adolescence to early adulthood, in this period individuals tend to explore various aspects of life, from love, work, to the world to get recognition from the world.

An important part of an individual who is growing up is self-esteem. Self-esteem is an important part of individuals, especially individuals who are growing up. Self-esteem related to mental health and social welfare (Abdel-Khalek, 2016; Moksnes \& Reidunsdatter, 2019; Sudrajat, 2020; Triwahyuningsih, 2017; Wang et al., 2017). The total view of oneself is very influential in various aspects of an individual's life. A person with low self-esteem, feels less 
confident about being able (has low self-efficacy), and his learning achievement will be low (Chen et al., 2018; Khotimah et al., 2016; Li et al., 2018; Mahmoudi, 2012; Shim et al., 2013). The results also show that high self-esteem is associated with alcohol use among students (Atalay et al., 2018; İnand1 et al., 2009); High commitment to their Facebook group (Coco et al., 2018), and video game interactions with specific patterns (Billieux et al., 2015). This shows that self-esteem is very important and influential in the lives of individuals, especially adults who are just growing up. (Billieux et al., 2015).

Self-esteem is a positive evaluation that is carried out thoroughly by individuals. Selfesteem is also defined as an evaluation of both positive and negative ones done by oneself (García et al., 2019; Rosenberg, 1965). Individuals who have high self-esteem can respect themselves, see themselves as valuable and can appreciate existing mistakes. Individual judgments will influence their behaviour. Self-esteem can be stable, it can also change, it takes time for individuals to develop, while trends and events in an individual's life can change an individual's self-esteem (Jan et al., 2017). Thus, all events experienced by individuals will affect the individual's self-esteem.

There are three factors that can affect a person's self-esteem, namely past experiences with family, feedback, and social comparisons (Myers, 2013; Van Tongeren \& Myers, 2016). Feedback received by individuals affects self-esteem, individuals who get negative feedback will be able to lower their self-esteem and vice versa ((Hasan et al., 2021; Putri et al., 2019; Valkenburg et al., 2006). Individuals with high self-esteem have the attributes: confident, friendly to others, happy, optimistic, high achievers, motivated, willing to take risks, adaptable, assertive, caring for others, and responsible. Meanwhile, individuals with low self-esteem have the following abilities: shyness, insecurity, underachievement, depression, poor self-image, insecurity, insecurity, and difficulties in communication.

Social media is very influential on a person's self-esteem. Individuals who have low self-esteem tend to benefit by opening themselves on Facebook rather than when they meet, but because the status update is concerned, they show more negative emotions which are ultimately perceived as less pleasant individuals (Marshall et al., 2015). Friends on social media who can respond quickly will be more able to meet the psychological needs of the individual than the number of friends themselves (Greitemeyer et al., 2014). This is also supported by the results of research which explains that the number of friends they have does not affect the level of a person's self-esteem (Tazghini \& Siedlecki, 2013). This explains that individuals will feel appreciated if there are friends who respond to them.

Individuals with low self-esteem will try to find many friends to increase their sense of belonging and create popularity (Tazghini \& Siedlecki, 2013). Individuals who feel or are imagining themselves to be someone who is accepted or considered popular by others can increase the individual's self-esteem. The feeling of being accepted and considered popular by others on social media will make individuals feel connected to social media itself. Previous research results show that there is a correlation between an individual's emotional attachment to social media and one's self-esteem (Burrow \& Rainone, 2017; Faraon \& Kaipainen, 2014; Tazghini \& Siedlecki, 2013; Vogel et al., 2014). Emotional attachment to social media is present because of a feeling of being accepted by other users, this acceptance makes the individual's self-esteem increase. Things that can be done to protect self-esteem are to give a good impression.

Someone will not post negative things because this will cause negative feedback which can then lower their self-esteem (Djafarova \& Trofimenko, 2017). A good self-presentation will make someone accepted by others who can then build their self-esteem ((Chiang \& Suen, 2015). This is possible because individual needs can be met when what is posted gets appreciation from others. Getting a good response from social media makes individuals feel that they are valued. 
Someone with low self-esteem will try to replace their social needs by being actively involved in online activities (Tazghini \& Siedlecki, 2013). These online activities include spending a lot of time on social media, the frequency of logging into social media, and having lots of friends on social media (Tazghini \& Siedlecki, 2013; Zhang et al., 2017)Finding and building lots of friendships on social media can take a lot of time.

The results of other studies show that the longer or more time spent using social media, in this case, Facebook, the self-esteem of the person will be lower ((Faraon \& Kaipainen, 2014; Jan et al., 2017). This decrease in self-esteem is because when using social media, someone is busier to make self-comparisons than to build friendships with other people. This selfcomparison can then make a person's self-esteem decrease.

A person with low self-esteem tends to worry about posts about himself and will spend a lot of time checking and deleting negative comments about him (Yau \& Reich, 2019). The results of other studies explain that low self-esteem reveals more negative things, tends to express sadness, anger, frustration, anxiety, fear, irritability, feelings of unhappiness, and a sense of lack of gratitude (Mackson et al., 2019). Unlike people who have low self-esteem, people with high self-esteem use social media to build self-image and more often post what they like and don't like, provide opinions, and perceptions on various things.

This study refers to the results regarding the use of social media Facebook with selfesteem (Faraon \& Kaipainen, 2014). The difference between this study and previous research is the social media users and the age of the research subject. In previous research, the social media used was Facebook, while this study used Instagram social media. Instagram was chosen because this social media is one of the most widely used social media in Indonesia. In addition, in this study, the focus of the age of the study subjects was in the age range 18-25 years, which is different from previous studies aged 20 to 66 years. Researchers chose emerging adulthood because around 23 million users out of 61,610,000 active Instagram users are aged 18-24 years, this age range includes the age range for emerging adulthood.

Social media such as Instagram can increase someone's self-esteem who was initially low, but can also reduce someone's self-esteem who was initially high. This is closely related to how someone uses social media. Someone who uses social media to build relationships with other people can increase that person's self-esteem. Conversely, someone who uses social media to compare himself with others will be able to reduce his self-esteem. Seeing the impact of using social media on self-esteem, this study aims to examine the relationship between the intensity of Instagram use and self-esteem in emerging adulthood.

\section{Method}

This research is a correlational study used to examine the relationship between the intensity of Instagram use and self-esteem on emerging adulthood users of Instagram. The technique used in this research sampling uses quota sampling by selecting participants based on predetermined characteristics so that the sample has the same characteristic distribution as the population. The population of this study were students at " $\mathrm{X}$ " University, male and female, aged 18-25 years, the number of students in the population was 784 people. The calculation of the number of samples in this study uses the Raosoft application. The results of the calculation obtained a sample size of 259 students.

The data collection process was carried out online considering that data collection was carried out during the Covid-19 pandemic. This study uses two measuring tools, namely: 1) measuring instrument Rosenberg Self Esteem Scale (RSES) which has been previously translated by Saleha (Saleha, 2014) with reliability $\alpha=0.822 .2)$ The Instagram Intensity Scale (IIS) measurement tool (Ellison et al., 2007) has been modified and adapted to this study with reliability $\alpha=0.83$. This measurement tool consists of 3 aspects, namely the number of Instagram friends, average time spent on Instagram per day in the past week, and emotional connectedness to the site. 
The analysis was carried out with the Spearman non-parametric correlation test, to test the relationship between the intensity of Instagram use and self-esteem and to test the intensity aspects of using Instagram with self-esteem. The non-parametric correlation test was used because the normality and linearity assumption tests had previously been carried out. Based on the results of the assumption test that has been carried out, it is known that the self-esteem variable has an abnormal data distribution.

\section{Results and Discussion}

\section{Result}

Table 1. Correlation Test Results

\begin{tabular}{lcc}
\hline Variable & Self-esteem & Conclusion \\
\hline Intensity of Use of Instagram & $0,149 *$ & Significant \\
- Number of Instagram friends & 0,074 & Unsignificant \\
- Average time spent on Instagram per day in the past week & 0,091 & Unsignificant \\
- Emotional connectedness to the site & $0,144^{*}$ & Significant \\
\hline * $<0,05$ & &
\end{tabular}

The results of data analysis are presented in table 1 . The results of the analysis show that there is a significant positive correlation between the intensity of using Instagram and selfesteem $(\mathrm{r}=0.149 ; \mathrm{r} 2=0.022 ; \mathrm{p}<0.05)$. This result can be interpreted that the higher the intensity of using Instagram among students, the higher their self-esteem. The $\mathrm{r} 2$ value obtained is 0.022 , this shows that the contribution of intensity of using Instagram to self-esteem is $2.22 \%$. The $2.22 \%$ figure is classified as small, this is probably because the research subjects are not differentiated between active users and passive users of Instagram. These results indicate that there is a significant correlation between the intensity of using Instagram and selfesteem. Of the three aspects of intensity of using Instagram, there is only one aspect that has a significant correlation with self-esteem, namely emotional connection to the site, while the other two aspects have no correlation with self-esteem.

\section{Discussion}

The results showed that there was a correlation between the intensity of using Instagram and self-esteem. The higher the intensity of using Instagram, the more energy it uses. This is supported by the results of research which explains that the frequency of using Instagram is correlated with symptoms of depression and self-esteem (Sherlock \& Wagstaff, 2019). This shows that the intensity of using Instagram greatly affects individual self-esteem. Researchers also found that there was a positive correlation on one aspect of the intensity of using Instagram with self-esteem, namely emotional connection to the site, while in the other two aspects there was no correlation. The results of this correlation can be interpreted that the higher a person's emotional attachment to Instagram, the higher the self-esteem. The emotions felt by individuals affect self-esteem and greater satisfaction with interpersonal relationships (Ruvalcaba-Romero et al., 2017).

Having a sense of comfort in expressing thoughts on Instagram can make a person emotionally attached. In addition, the feeling of being accepted from other people can also make individuals emotionally attached to Instagram. Increased emotions in the form of feelings of happiness and the presence of people who like them are one of the positive things that can be obtained from using Instagram (Kircaburun \& Griffiths, 2019). This sense of acceptance makes individuals want to get recognition or have a good image on Instagram. Feelings of 
being accepted by other Instagram users are shown by giving positive comments or liking posts (Santi, 2017).

Most of the subjects reported having received positive comments. The positive comments you get will make someone feel welcome. Self-esteem can increase when or someone imagines himself to be included, accepted, or considered popular by others. Trust, acceptance, and positive feedback characterize the diversity of interactions on Instagram that make individuals feel that they are valuable (Berard \& Smith, 2019). The more individuals feel accepted and feel comfortable on Instagram, it means the higher the individual's emotional attachment to Instagram which can increase the individual's self-esteem.

Another finding in this study is that most of the subjects often view video or photo content when using Instagram. This allows users to repost previously watched content and provide opinions about the content. Giving an opinion or opinion shows a sense of comfort in expressing thoughts and in showing yourself on Instagram. Individuals with high self-esteem use social media to build self-image and will more often post what they like and don't, opinions about things, and perceptions about various things (Jiang \& Ngien, 2020; Taber \& Whittaker, 2018; Young et al., 2012).

This result is different from the results of previous studies which found that emotional attachment and self-esteem were negatively correlated (Faraon \& Kaipainen, 2014; Tazghini $\&$ Siedlecki, 2013). This is possible because of the cultural differences of the research subjects. Most of the subjects in this study claimed to have many friends on Instagram. Based on the results of the analysis, there was no correlation between the number of Instagram friends and self-esteem $p(0.074)>0.05$. This result means that many or at least friends on Instagram social media are not related to self-esteem. The number of friends on Instagram, in this case the followers and following, does not describe the friendship that is built. This is because not all of the followers or following are friends, but rather idolized public figures.

Building many relationships on social media can increase individual self-esteem (Ellison et al., 2007; Jan et al., 2017; Kim \& Kim, 2019). Friends who are more responsive can meet psychological needs in this case self-esteem than the number of friends itself (Greitemeyer et al., 2014). The number of friends on Instagram does not correlate with selfesteem because the number of followers and following Instagram does not actually describe the friendship that is built. This result is different from previous research in that the number of friends is negatively correlated with self-esteem (Faraon \& Kaipainen, 2014). However, these results are consistent with research which explains that the number of friends on social media is not related to one's self-esteem (Tazghini \& Siedlecki, 2013). Most of the subjects are classified as very low in their time using Instagram and the activity they often do is viewing video or photo content. Very low time or relatively short time is used to use Instagram which allows individuals to only view video or photo content without making self-comparisons or building friendships that can affect self-esteem.

\section{Conclusions and Suggestions}

Based on the results of the study, it was found that the higher the intensity of using Instagram, the higher the self-esteem of emerging adulthood. The use of Instagram allows individuals to make self-comparisons or build a positive self-image for individuals. Further research is expected to be carried out with a wider population, for example in adolescents, to add other factors related to self-esteem, for example regarding popularity on Instagram social media and feedback such as likes. In addition, the data collection method is also more attention, considering that the data collection of this research is done online. 


\section{References}

Abdel-Khalek, A. M. (2016). Introduction to the psychology of self-esteem. Self-Esteem: Perspectives, Influences, and Improvement Strategies, 1-23.

Arnett, J. J. (2014). Emerging adulthood: The winding road from the late teens through the twenties. Oxford University Press.

Arnett, J. J. (2015). The Oxford handbook of emerging adulthood. Oxford University Press.

Arnett, J. J. (2018). Conceptual foundations of emerging adulthood. In Emerging Adulthood and Higher Education (pp. 11-24). Routledge.

Atalay, B. I., Unal, E., Onsuz, M. F., Isikli, B., Yenilmez, C., \& Metintas, S. (2018). Violence and related factors among high school students in semirural areas of Eskisehir. Northern Clinics of Istanbul, 5(2), 125.

Berard, A. A., \& Smith, A. P. (2019). Post your journey: Instagram as a support community for people with fibromyalgia. Qualitative Health Research, 29(2), 237-247.

Billieux, J., Thorens, G., Khazaal, Y., Zullino, D., Achab, S., \& Van der Linden, M. (2015). Problematic involvement in online games: A cluster analytic approach. Computers in Human Behavior, 43, 242-250.

Boyd, D. M., \& Ellison, N. B. (2007). Social network sites: Definition, history, and scholarship. Journal of Computer-mediated Communication, 13(1), 210-230.

Burrow, A. L., \& Rainone, N. (2017). How many likes did I get?: Purpose moderates links between positive social media feedback and self-esteem. Journal of Experimental Social Psychology, 69, 232-236.

Chen, Z., Sun, K., \& Wang, K. (2018). Self-esteem, achievement goals, and self-handicapping in college physical education. Psychological Reports, 121(4), 690-704.

Chiang, J. K.-H., \& Suen, H.-Y. (2015). Self-presentation and hiring recommendations in online communities: Lessons from LinkedIn. Computers in Human Behavior, 48, 516524.

Coco, G. Lo, Maiorana, A., Mirisola, A., Salerno, L., Boca, S., \& Profita, G. (2018). Empirically-derived subgroups of Facebook users and their association with personality characteristics: a Latent Class Analysis. Computers in Human Behavior, 86, 190-198.

Djafarova, E., \& Trofimenko, O. (2017). Exploring the relationships between self-presentation and self-esteem of mothers in social media in Russia. Computers in Human Behavior, 73, 20-27.

Duarte, F. (2019). Berapa banyak waktu yang dihabiskan rakyat Indonesia di media sosial? Www.Bbc.Com/Indonesia/Majalah-49630216. www.bbc.com/indonesia/majalah49630216

Ellison, N. B., Steinfield, C., \& Lampe, C. (2007). The benefits of Facebook "friends:" Social capital and college students' use of online social network sites. Journal of ComputerMediated Communication, 12(4), 1143-1168.

Faraon, M., \& Kaipainen, M. (2014). Much more to it: The relation between Facebook usage and self-esteem. Proceedings of the 2014 IEEE 15th International Conference on Information Reuse and Integration (IEEE IRI 2014), 87-92.

Fitch, C. E. (2018). Emerging Adulthood and the Criminal Justice System:\# Brainnotfullycooked\# Can'tadultyet\# Yolo. Santa Clara L. Rev., 58, 325.

García, J. A., y Olmos, F. C., Matheu, M. L., \& Carreño, T. P. (2019). Self esteem levels vs global scores on the Rosenberg self-esteem scale. Heliyon, 5(3), e01378.

Greitemeyer, T., Mügge, D. O., \& Bollermann, I. (2014). Having responsive Facebook friends affects the satisfaction of psychological needs more than having many Facebook friends. Basic and Applied Social Psychology, 36(3), 252-258.

Hasan, U. R., Nur, F., Rahman, U., Suharti, S., \& Damayanti, E. (2021). Self Regulation, Self 
Esteem, dan Self Concept Berpengaruh Terhadap Prestasi Belajar Matematika Peserta Didik. ANARGYA: Jurnal Ilmiah Pendidikan Matematika, 4(1), 38-45.

Imam, M. (2020). Pengguna instagram di Indonesia didominasi wanita dan generasi milenial. https://www.goodnewsfromindonesia.id/2020/06/14/pengguna-instagram-di-indonesiadidominasi-wanita-dan-generasi-milenial

İnand1, T., Özer, C., Akdemir, A., Akoğlu, S., Babayiğit, C., Turhan, E., \& Sangün, Ö. (2009). Violence, psychological features, and substance use in high school students in Hatay: A cross-sectional study.

Jan, M., Soomro, S., \& Ahmad, N. (2017). Impact of social media on self-esteem. European Scientific Journal, 13(23), 329-341.

Jiang, S., \& Ngien, A. (2020). The Effects of Instagram Use, Social Comparison, and SelfEsteem on Social Anxiety: A Survey Study in Singapore. Social Media+ Society, 6(2), 2056305120912488.

Khotimah, R. H., Radjah, C. L., \& Handarini, D. M. (2016). Hubungan antara konsep diri akademik, efikasi diri akademik, harga diri dan prokrastinasi akademik pada siswa SMP negeri di kota malang. Jurnal Kajian Bimbingan Dan Konseling, 1(2), 60-67.

Kim, B., \& Kim, Y. (2019). Growing as social beings: How social media use for college sports is associated with college students' group identity and collective self-esteem. Computers in Human Behavior, 97, 241-249.

Kurcaburun, K., \& Griffiths, M. D. (2019). Problematic Instagram use: The role of perceived feeling of presence and escapism. International Journal of Mental Health and Addiction, 17(4), 909-921.

Lantagne, A., Furman, W., \& Novak, J. (2017). "Stay or Leave" Predictors of Relationship Dissolution in Emerging Adulthood. Emerging Adulthood, 5(4), 241-250.

Li, J., Han, X., Wang, W., Sun, G., \& Cheng, Z. (2018). How social support influences university students' academic achievement and emotional exhaustion: The mediating role of self-esteem. Learning and Individual Differences, 61, 120-126.

Mackson, S. B., Brochu, P. M., \& Schneider, B. A. (2019). Instagram: Friend or foe? The application's association with psychological well-being. New Media \& Society, 21(10), 2160-2182.

Mahmoudi, A. (2012). Effect of self-esteem and self-efficacy in family dynamics. ProcediaSocial and Behavioral Sciences, 46, 53-56.

Marshall, T. C., Lefringhausen, K., \& Ferenczi, N. (2015). The Big Five, self-esteem, and narcissism as predictors of the topics people write about in Facebook status updates. Personality and Individual Differences, 85, 35-40.

Moksnes, U. K., \& Reidunsdatter, R. J. (2019). Self-esteem and mental health in adolescentslevel and stability during a school year. Norsk Epidemiologi, 28(1-2).

Myers, D. J. (2013). Social psychology's contribution to a sustainable future. J. Manag. Glob. Sustain, 1, 7-28.

Pertiwi, W. K. (2020). Sebanyak inikah jumlah pengguna instagram di indonesia?. https://tekno.kompas.com/read/2019/12/23/14020057/sebanyak-inikah-jumlahpengguna-instagram-di-indonesia

Pradiani, T. (2017). Pengaruh sistem pemasaran digital marketing terhadap peningkatan volume penjualan hasil industri rumahan. Jurnal Ilmiah Bisnis Dan Ekonomi Asia, 11(2), $46-53$.

Putri, I. N., Ahied, M., \& Rosidi, I. (2019). Pengaruh Model Pembelajaran ARCS (Attention, Relevance, Confidence, Satisfaction) terhadap Self Esteem Siswa. Natural Science Education Research, 2(1), 1-7.

Rahadi, D. R. (2017). Perilaku pengguna dan informasi hoax di media sosial. Jurnal Manajemen Dan Kewirausahaan, 5(1), 58-70. 
Rarasati, D. B., Hudaniah, H., \& Prasetyaningrum, S. (2019). Strategi presentasi diri pengguna instagram ditinjau dari tipe kepribadian. Jurnal Ilmiah Psikologi Terapan, 7(2), 235-251.

Rosenberg, M. (1965). Rosenberg self-esteem scale (RSE). Acceptance and Commitment Therapy. Measures Package, 61(52), 18.

Ruvalcaba-Romero, N. A., Fernández-Berrocal, P., Salazar-Estrada, J. G., \& GallegosGuajardo, J. (2017). Positive emotions, self-esteem, interpersonal relationships and social support as mediators between emotional intelligence and life satisfaction. Journal of Behavior, Health \& Social Issues, 9(1), 1-6.

Saleha, P. A. (2014). Hubungan antara Prokrastinasi Umum dan Prokrastinasi Akademik dengan Self-Esteem.

Santi, N. N. (2017). Dampak kecenderungan narsiscisme terhadap self esteem pada pengguna facebook mahasiswa PGSD UNP. Jurnal Dimensi Pendidikan Dan Pembelajaran, 5(1), 25-30.

Sherlock, M., \& Wagstaff, D. L. (2019). Exploring the relationship between frequency of Instagram use, exposure to idealized images, and psychological well-being in women. Psychology of Popular Media Culture, 8(4), 482.

Shim, S. S., Wang, C., \& Cassady, J. C. (2013). Emotional well-being: The role of social achievement goals and self-esteem. Personality and Individual Differences, 55(7), 840845.

Sudrajat, A. (2020). Apakah Media Sosial Buruk untuk Kesehatan Mental dan Kesejahteraan? Kajian Perspektif Remaja. Jurnal Tinta, 2(1), 41-52.

Taber, L., \& Whittaker, S. (2018). Personality depends on the medium: differences in selfperception on Snapchat, Facebook and offline. Proceedings of the 2018 CHI Conference on Human Factors in Computing Systems, 1-13.

Tazghini, S., \& Siedlecki, K. L. (2013). A mixed method approach to examining Facebook use and its relationship to self-esteem. Computers in Human Behavior, 29(3), 827-832.

Triwahyuningsih, Y. (2017). Kajian meta-analisis hubungan antara self esteem dan kesejahteraan psikologis. Buletin Psikologi, 25(1), 26-35.

Twenge, J. M., Martin, G. N., \& Spitzberg, B. H. (2019). Trends in US Adolescents' media use, 1976-2016: The rise of digital media, the decline of TV, and the (near) demise of print. Psychology of Popular Media Culture, 8(4), 329.

Valkenburg, P. M., Peter, J., \& Schouten, A. P. (2006). Friend networking sites and their relationship to adolescents' well-being and social self-esteem. CyberPsychology \& Behavior, 9(5), 584-590.

Van Tongeren, D. R., \& Myers, D. G. (2016). A social psychological perspective on humility. In Handbook of humility (pp. 166-180). Routledge.

Vogel, E. A., Rose, J. P., Roberts, L. R., \& Eckles, K. (2014). Social comparison, social media, and self-esteem. Psychology of Popular Media Culture, 3(4), 206.

Wang, Z., Liu, H., Yu, H., Wu, Y., Chang, S., \& Wang, L. (2017). Associations between occupational stress, burnout and well-being among manufacturing workers: mediating roles of psychological capital and self-esteem. BMC Psychiatry, 17(1), 1-10.

Yau, J. C., \& Reich, S. M. (2019). "It's Just a Lot of Work": Adolescents' Self-Presentation Norms and Practices on Facebook and Instagram. Journal of Research on Adolescence, 29(1), 196-209.

Young, C. B., Wu, S. S., \& Menon, V. (2012). The neurodevelopmental basis of math anxiety. Psychological Science, 23(5), 492-501.

Zhang, Y., Trusov, M., Stephen, A. T., \& Jamal, Z. (2017). Online shopping and social media: friends or foes? Journal of Marketing, 81(6), 24-41. 